Unang Wirastri, Nani Nurhaeni, Elfi Syahreni

Aplikasi Teori Comfort Dalam Asuhan Keperawatan Pada Anak Dengan Demam Di Ruang Infeksi Anak RSUPN Dr. Cipto Mangunkusumo

\title{
APLIKASI TEORI COMFORT KOLCABA DALAM ASUHAN KEPERAWATAN PADA ANAK DENGAN DEMAM DI RUANG INFEKSI ANAK
}

\author{
Unang Wirastri $^{1}$, Nani Nurhaeni ${ }^{2}$, Elfi Syahreni ${ }^{3}$ \\ ${ }^{1)}$ RSUD Prof.Dr.Margono Soekarjo Purwokerto \\ 2), 3) Fakultas Ilmu Keperawatan Universitas Indonesia
}

\begin{abstract}
Abstrak
Demam merupakan gejala yang sering dialami anak dengan penyakit infeksi. Kondisi demam tinggi berdampak merugikan anak. Demam tinggi membuat anak tidak nyaman dan orang tua cemas serta meningkatkan kebutuhan kalori dan cairan. Teori Comfort dari Kolcaba memberikan arahan dalam pemenuhan rasa nyaman pada pasien. Karya ilmiah ini bertujuan memberikan gambaran asuhan keperawatan pada anak demam dengan mengaplikasikan teori comfort Kolcaba yang berfokus pada pemenuhan kebutuhan kenyamanan. Asuhan keperawatan dilakukan berdasarkan tahapan comfort yaitu pengkajian (kenyamanan fisik, psikospiritual, lingkungan, dan sosiokultural), merumuskan diagnosa keperawatan, menetapkan intervensi (berdasarkan standar comfort, coaching, dan comfort food for the soul), implementasi, dan evaluasi. Berdasarkan 5 kasus yang dibahas, intervensi yang diberikan untuk masalah keperawatan peningkatan suhu tubuh (demam) antara lain mengupayakan penurunan suhu tubuh, mempertahankan lingkungan sejuk dan nyaman, meningkatkan istirahat, memberikan asupan cairan dan nutrisi adekuat serta menurunkan kecemasan anak dan orang tua menggunakan konsep family centered care. Teori comfort Kolcaba dapat diterapkan dalam asuhan anak demam. Disarankan untuk lebih meningkatkan kenyamanan fisik, psikospiritual, lingkungan, dan sosiokultural sehingga terlihat bahwa ke empat aspek kenyamanan harus saling mendukung untuk pencapaian kenyamanan secara holistik.
\end{abstract}

Kata kunci: teori comfort Kolcaba; anak demam; infeksi

\section{PENDAHULUAN}

Demam pada anak merupakan hal yang paling sering dikeluhkan oleh orang tua, di tempat praktek dokter maupun di Unit Gawat Darurat (UGD) anak, meliputi 10-20\% dari jumlah kunjungan (Kania, 2007). Demam merupakan masalah yang sering dihadapi oleh tenaga kesehatan dan orang tua baik di rumah sakit maupun di rumah. Demam menyebabkan orang tua atau pengasuh merasa khawatir (Finkelstein, Christiansen \& Platt, 2000; Crocetti, Moghbelli \& Serwint, 2001).

Demam terjadi karena adanya kenaikan set point di hipotalamus akibat infeksi atau ketidakseimbangan antara produksi dan pengeluaran panas. Jevon (2010) menyatakan bahwa sebagian besar demam berhubungan dengan infeksi yang dapat berupa infeksi. Demam paling sering sekitar $50 \%$ disebabkan oleh penyakit infeksi. Masalah pada kondisi demam tinggi adalah meningkatnya laju metabolik. (Ismoejanto, 2000; Potter \& Perry, 2005).

Keluhan demam pada bayi dan balita merupakan salah satu alasan orang tua untuk membawa anak ke dokter/berobat ke rumah sakit (Schmitt, 1991). Kondisi demam yang dialami anak juga disertai gejala lain seperti takikardi, takipnea serta anak menjadi gelisah dan rewel. Demam yang terus menerus menyebabkan orang tua cemas. Hal ini tentu menimbulkan rasa tidak nyaman pada pasien maupun orang tua.

Anak akan mulai merasakan ketidaknyamanan dan akral teraba dingin ketika suhu tubuh sudah di atas $38,5^{\circ} \mathrm{C}$. 
Masalah lain pada kondisi demam tinggi adalah meningkatnya laju metabolik. Laju metabolik meningkat $10 \%$ untuk setiap kenaikan suhu tubuh satu derajat celsius dan meningkat tiga sampai lima kali selama menggigil serta akan meningkatkan kebutuhan oksigen, cairan, dan kalori (Ismoejanto, 2000; Potter \& Perry, 2005).

Demam menyebabkan gangguan rasa nyaman yang perlu diatasi. Rasa nyaman merupakan bagian dari keperawatan yang penting untuk diperhatikan. Kenyamanan diartikan sebagai kondisi sejahtera dan merupakan tahap berakhirnya tindakan keperawatan yang dilakukan kepada klien. Kenyamanan merupakan nilai dasar yang menjadikan tujuan keperawatan pada setiap waktu (Siefert, 2002). Pendekatan teori comfort yang dikembangkan oleh Kolcaba menawarkan kenyamanan sebagai bagian terdepan dalam proses keperawatan. Kolcaba memandang bahwa kenyamanan holistik adalah kenyamanan yang menyeluruh meliputi kenyamanan fisik, psikospiritual, lingkungan, dan psikososial. Tingkat kenyamanan terbagi menjadi tiga yaitu relief dimana pasien memerlukan kebutuhan kenyamanan yang spesifik, ease yaitu terbebas dari rasa ketidaknyamanan atau meningkatkan rasa nyaman, dan transcendence yaitu mampu mentoleransi atau dapat beradaptasi dengan ketidaknyamanan (Kolcaba \& Dimarco, 2005; Tomey \& Alligood, 2006). Pada studi kasus ini dijelaskan contoh pengkajian kenyamanan berdasarkan teori comfort, pengelompokkan masalah ke dalam kolom taksonomi untuk memudahkan intervensi dalam pemenuhan kebutuhan kenyamanan pada anak.

Diperlukan kerja sama antara tenaga perawat dan keluarga pasien untuk memenuhi kebutuhan kenyamanan yang holistik yaitu kenyamanan fisik, psikospiritual, lingkungan, dan sosiokultural. Perawat perlu melibatkan keluarga baik orang tua pasien maupun keluarga besar. Keterlibatan keluarga mutlak diperlukan pada perawatan anak karena keluarga adalah bagian yang tidak dapat dipisahkan dari anak. Anggota keluarga terutama orang tua mempunyai peran yang sangat penting dalam meningkatkan kesehatan atau kesejahteraan pasien. Keluarga menjadi sumber utama dalam memberikan kekuatan dan dukungan kepada anak (Neal, Frost, Kuhn, Green, Cleveland \& Kersten, 2007).

Hal ini yang menjadi latar belakang penulis membuat karya ilmiah penerapan aplikasi teori comfort Kolcaba untuk mengatasi masalah demam pada anak yang mengalami infeksi di RUPN Dr. Cipto Mangunkusumo Jakarta.

\section{Aplikasi Teori Keperawatan pada Asuhan Keperawatan}

Teori comfort mengedepankan kenyamanan sebagai kebutuhan semua manusia. Kenyamanan adalah kebutuhan yang diperlukan pada rentang sakit sampai sehat dan kenyamanan merupakan lebel tahap akhir dari tindakan terapeutik perawat terhadap pasien (Siefert, 2002). Menurut Kolcaba, comfort mempunyai arti yang holistik dan kompleks. Kolcaba dalam teori comfort yang dikembangkan menyebutkan holistic comfort merupakan bentuk keyamanan yang meliputi tiga tipe comfort yaitu relief, ease dan transcendence yang digabungkan dalam empat konteks yaitu physical, psychospiritual, sociocultural dan environmental (Kolcaba \& Dimarco, 2005).

Relief didefinisikan sebagai keadaan dimana rasa tidak nyaman berkurang atau menemukan kebutuhan yang spesifik. Ease diartikan sebagai keadaan tenang atau kepuasan. Transcendence merupakan tahapan dimana seseorang mampu beradaptasi terhadap masalahnya. Physical comfort atau kenyamanan fisik meliputi kebutuhan pasien akan status hemodinamik (kebutuhan cairan, elektrolit, pernafasan, 
suhu tubuh, eliminasi, sirkulasi, metabolisme, nutrisi dan lain-lain), nyeri dan kenyamanan manajemen nyeri, ketidaknyamanan fisik lainnya (yang dirasakan saat ini atau potensial), kurangnya sensori (alat bantu dengar, kacamata, bicara pelan, proses berfikir lama). Psychospiritual comfort atau kenyamanan psikospiritual antara lain kebutuhan dihadirkan rohaniawan, kecemasan, ketakutan, berdoa dengan perawat atau yang lainnya, persepsi terhadap penyakit, persepsi terhadap hidup dan pengalaman hidup. Sociocultural comfort atau kenyamanan sosial budaya meliputi keuangan, perencanaan pulang, rutinitas dirumah sakit, kebutuhan pendidikan kesehatan atau informasi kesehatan, kunjungan teman atau kerabat, hubungan dengan orang lain, dukungan atau kekuatan, ketersediaan tenaga untuk keberlanjutan perawatan di rumah. Environmental comfort atau kenyamanan lingkungan meliputi privasi, bau, kebisingan, pencahayaan, tempat tidur yang nyaman, hiasan ruangan dan lain-lain (Kolcaba, Tilton \& Drouin, 2006).

\section{METODE}

Program pendidikan residensi keperawatan anak dilaksanakan dengan tujuan menghasilkan lulusan yang mampu memberikan asuhan keperawatan kepada klien anak dan keluarganya secara mandiri. Kompetensi yang ditetapkan meliputi praktik profesional, legal dan etis, pemberian asuhan dan manajemen asuhan serta pengembangan profesional. Untuk mencapai kompetensi tersebut, mahasiswa dituntut menerapkan berbagai konsep dan teori kesehatan, temuan riset serta kebijakan pemerintah yang berlaku pada anak sehat maupun sakit dengan penyakit akut, kronik dan neonatus pada saat melakukan praktik residensi keperawatan (Tim Ners Spesialis Keperawatan Anak, 2013).
Beberapa peran perawat telah dilakukan sebagai pemberi asuhan, advokat, konsultan, pendidik, kolaborasi, peneliti dan agen pembaharu (Wong, Eaton, Wilson, Winkelstein, \& Schwartz, 2009). Sebagai agen pembaharu residen mengadakan proyek inovasi berupa penilaian pada anak demam berdasarkan Yale Observation Scale (YOS).

\section{PEMBAHASAN}

Langkah awal asuhan keperawatan menggunakan teori Comfort Kolcaba adalah pengkajian. Pengkajian dilakukan untuk mengumpulkan data klien. Pengumpulan data dilakukan melalui wawancara, observasi, pemeriksaan fisik dan pemeriksaan penunjang. Pengkajian keperawatan dilakukan dengan pendekatan teori comfort yaitu memperhatikan aspek kenyamanan fisik, psikospiritual, sosiokultural dan lingkungan. Pengkajian yang dilakukan berdasarkan keempat konteks kenyamanan selanjutnya dimasukkan ke dalam taksonomi comfort untuk memudahkan perawat dalam melakukan intervensi.

Adanya peningkatan suhu tubuh (demam) dapat dikaji melalui tanda-tanda yang menyertainya seperti takikardia, takipnea, kulit teraba hangat serta kulit dan bibir tampak kemerahan (Potter \& Perry, 2005). Tanda dan gejala tersebut dapat ditemukan saat melakukan pengkajian pada aspek kenyamanan fisik.

Intervensi keperawatan pada teori comfort dikategorikan dalam tiga tipe intervensi yaitu intervensi untuk kenyamanan standar (standar comfort), intervensi untuk pembinaan (coaching), dan intervensi yang berhubungan dengan memberikan kenyamanan jiwa (comfort food for the soul). Intervensi untuk kenyamanan standar adalah intervensi untuk mempertahankan hemodinamik, mengontrol nyeri, dan mengatasi demam. Intervensi untuk pembinaan yaitu intervensi yang digunakan untuk 
menurunkan kecemasan, menyediakan informasi kesehatan, mendengarkan harapan pasien dan membantu pasien untuk sembuh. Sedangkan intervensi yang berhubungan dengan memberikan kenyamanan jiwa yaitu melakukan sesuatu yang menyenangkan untuk membuat keluarga dan pasien merasa diberikan kepedulian dan meningkatkan semangat, contohnya melakukan massage dan melakukan imajinasi terbimbing (Kolcaba \& Dimarco, 2005).

Implementasi merupakan tahapan perawat memberikan perawatan langsung sesuai dengan rencana keperawatan yang telah disusun berdasarkan masalah dan tujuan keperawatan (Aligood \& Tomey, 2006). Perawat menggunakan pendekatan intervensi berdasarkan prinsip comfort Kolcaba yaitu intervensi dalam pemenuhan kebutuhan rasa nyaman baik dari segi fisik, psikospiritual, sosiokultural dan lingkungan.

Asuhan keperawatan yang diberikan kepada lima klien kelolaan menunjukkan masalah keperawatan yang bervariasi dan semuanya dapat teratasi. Keberhasilan implementasi keperawatan tergantung keunikan masing-masing individu dalam merespon kondisi tubuhnya.

Kendala yang ditemui residen keperawatan anak antara lain terbentur dengan masalah teknis yang ada. Residen keperawatan anak merasa kesulitan untuk mengkondisikan lingkungan seperti orang tua/keluarga pasien yang berasal dari berbagai daerah sehingga seringkali terkendala oleh kebiasaan mereka untuk membiasakan cuci tangan. Selain kebiasaan, tingkat pengetahuan juga mempengaruhi mereka untuk membiasakan cuci tangan. Hal ini dapat berdampak kurang baik pada perawatan yang diberikan karena bisa meningkatkan risiko kejadian infeksi nosokomial, sehingga masa rawat menjadi semakin memanjang terutama pada klien yang berisiko tinggi mengalami infeksi. Namun demikian residen keperawatan anak tetap memotivasi keluarga untuk melakukan cuci tangan pada air mengalir dengan menggunakan sabun sebelum dan sesudah kontak dengan klien. personal pada bayi dan toddler.

\section{KESIMPULAN}

Teori comfort Kolcaba dapat diaplikasikan pada pemberian asuhan keperawatan dengan demam pada anak yang mengalami infeksi. Teori ini dapat membantu meningkatkan kenyamanan terhadap proses perubahan yang terjadi pada anak akibat penyakit yang dialaminya. Pendekatan teori comfort Kolcaba dalam melakukan asuhan keperawatan pada pasien demam secara umum dapat diterapkan. Teori comfort dapat juga diterapkan dalam mengatasi kecemasan yang dipengaruhi oleh faktor sosiokultural akibat dukungan keluarga. Kepuasan keluarga menjadi meningkat dengan keterlibatan keluarga dalam perawatan pada anak demam.

Intervensi yang dilakukan untuk masalah peningkatan suhu tubuh adalah dengan pemberian antipiretik dan peningkatan pengeluaran panas melalui berbagai metode. Intervensi lainnya adalah dengan meningkatkan istirahat, asupan nutrisi dan cairan, pemantauan keseimbangan cairan serta memfasilitasi interaksi anak dan keluarga melalui family centered care.

Pencapaian kompetensi dari beberapa area praktik telah memperkaya pengalaman residen. Berbagai peran perawat baik sebagai pemberi asuhan, advokat, konselor, pendidik, kolaborator, konsultan dan agen pembaharu telah dilakukan selama praktik. Namun kendala tetap ada, meskipun demikian tidak mengurangi pencapaian target kompetensi yang telah ditetapkan

Penerapan teori comfort Kolcaba dapat dijadikan acuan dalam melakukan asuhan keperawatan pada pasien di ruang infeksi anak, terutama pasien demam yang 
mengalami pada masalah kenyamanan. Teori ini dapat diaplikasikan dan berfokus pada tingkat kenyamanan pasien secara fisik, psikospiritual, lingkungan dan sosiokultural sehingga mampu memenuhi kebutuhan kenyamanan secara menyeluruh.

Intervensi keperawatan yang dilakukan berhubungan dengan kebutuhan kenyamanan pasien demam sangat disarankan untuk melibatkan keluarga. Hal ini karena kehadiran dan keterlibatan keluarga terbukti efektif dalam membantu mengantisipasi kejadian yang tidak diinginkan saat anak demam.

Perawat hendaknya lebih meningkatkan perannya, tidak hanya sebagai pemberi asuhan keperawatan, namun juga peran sebagai advokator, edukator, konselor, dan inovator. Melalui peran tersebut, perawat dapat meningkatkan pengetahuan dan ketrampilan keluarga dalam merawat anak dengan demam dengan cara pemberian pendidikan kesehatan.

Perawat diharapkan meneruskan proyek inovasi yang telah dilaksanakan yaitu tentang penilaian pada anak demam berdasarkan Yale Obervational Score (YOS), sehingga hasilnya dapat dijadikan dasar dalam mengambil keputusan untuk pembuatan SOP.

Perawat hendaknya lebih meningkatkan perannya, tidak hanya sebagai pemberi asuhan keperawatan, namun juga peran sebagai advokator, edukator, konselor, dan inovator. Melalui peran tersebut, perawat dapat meningkatkan pengetahuan dan ketrampilan keluarga dalam merawat anak dengan demam dengan cara pemberian pendidikan kesehatan.

\section{DAFTAR PUSTAKA}

Crocetti, M., Moghbelli, N., \& Serwint, J. (2001). Fever phobia revisited: Have parental misconceptions about fever changed in 20 years. Pediatric, (107), 1241-6.

Finkelstein, J.A., Christiansen, C. L., \& Platt, R. (2000). Fever in pediatric primary care: Occurrence, management and outcome. Pediatric, (105), 260-6.

Ismoejanto. (2000). Demam pada anak. Sari Pediatri, 2 (2), 103-108.

Jevon, P. (2010). How to ensure patient observations lead to effective management of patients with pyrexia. Nursing Times, 106 (1), early online publication.

Kania, N. (2007). Penatalaksaan demam pada anak.

http://pustaka.unpad.ac.id/wpcontent/uploads/2010/02/penatalaksa naan_demam_pada_anak.pdf. Diperoleh 10 September 2014.

Kolcaba, K., \& DiMarco, M. A. (2005). Comfort theory and its application to pediatric nursing. Pediatric Nursing, 31(3), 187-194.

Kolcaba, K., Tilton, C., \& Drouin, C.(2006). Comfort theory a unifying framework to enhance the practice environment. The Journal of Nursing Administration, 36 (11), 538-544.

Potter, P.A., Perry, A.G. (2005). Buku Ajar Fundamental Keperawatan: Konsep, Proses Dan Praktik. Edisi 4. Volume 1. Jakarta: EGC.

Tomey, M.A., \& Alligood, M.R. (2006). Nursing theory and their work. $6^{\text {th }}$ edition. Philadelphia: Elsevier.

Wong, L. D., Hockenberry, M., Willson, D., Winkelstein, M., \& Schwartz, P. (2009). Buku ajar keperawatan pediatrik (Agus Sutarna, Eni Juniarti \& H.Y Kuncara, Penerjemah). Jakarta:EGC. 